\title{
Energy and Exergy Analysis of a Cylindrical Hot Water Storage Tank: Experimental and CFD Analysis
}

\author{
Tomas Kropas ${ }^{*}$, Giedrè Streckienè \\ Faculty of Environment Engineering, Vilnius Gediminas Technical University, Vilnius, Lithuania
}

Received 18 February 2020; accepted 04 March 2020

\begin{abstract}
Active solar water heating systems typically include hot water storage tanks. The selection of the storage system strongly affects the performance of the entire system. This article presents a detailed analysis of a hot water storage tank during charging and dynamic charging-discharging mode. A numerical model using computational fluid dynamics for the storage tank was developed to investigate the temperature distribution inside of it. Transient thermal analysis was carried using ANSYS Fluent. The numerical model was validated with the experimental results. The energy and exergy analysis as an important tool for the evaluation of the thermal systems quantitatively and qualitatively was performed. The calculation procedures were described. The energy and exergy efficiencies, heat losses were calculated for steady and dynamic processes. Effect of mass flow rate was analysed. The results from parametric analysis showed that charging dynamics reduced the thermocline and efficiency of the hot water storage tank. The dependency of the exergy efficiency of the heat storage tank on the reference environment temperature during the dynamic operation was analysed. Exergy efficiencies for two cities with different climates were compared. This indicated that the higher environmental temperature gave lower exergy efficiency of the storage tank.
\end{abstract}

Keywords: heat storage tank, energy efficiency, exergy efficiency, computational fluid dynamics (CFD), fluid flow, environmental temperature, climate.

\section{Introduction}

Currently, hot water storage tanks are the most common devices used to store heat in solar thermal energy systems (Džiugaitė-Tumėnienė \& Streckienè, 2014; Wang et al., 2019). The use of these and other energy storage systems (latent heat storage tanks, compressed air technologies, batteries etc.) contributes to the global goals of energy efficiency, decarbonisation, utilization of renewable and waste energy. Therefore, a comprehensive analysis of these systems is needed both quantitatively and qualitatively.

One of the main focus area in thermal energy storage is improvement in the efficiency of energy storage and total system (Alva et al., 2017). These improvements can be evaluated by different methods and efficiencies: stratification efficiency (Haller et al., 2009), energy efficiency, exergy efficiency and others (Njoku et al., 2016; Kropas et al., 2019). In order to reach higher efficiencies, stratified storage tanks are used. Thermal stratification allows to minimize mixing effect and maintain high thermal efficiency at demand side and energy collection side (Chandra \& Matuska, 2019). The energy storage efficiency and the whole system can be increased up to $6 \%$ and $20 \%$, respectively with comparison between the fully stratified water tank and the fully mixed water tank (Ghaddar, 1994; Li, 2016). The formed stratification depends on various factor: aspect ratio (Bai et al., 2019), flow rates (Streckiene \& Miseviciute, 2011), the relative Reynold's numbers of heat transfer fluids in heat exchangers, their location and dimensions (Rahman et al., 2016), design of the inlet port of the tank and baffle size ( $\mathrm{Li}, 2016)$. Fertahi et al. presented a review on stratification studies and efficiency indicators (Fertahi et al., 2018).

Computer simulations are increasingly being used to study domestic hot water (DHW) storage tanks (Arslan \& Igci, 2015). This allows deeper analysis and investigation of more parameters influencing thermal stratification. Arslan and Igci studied a vertical solar DHW tank with a mantle heat exchanger. They observed that higher temperature difference between the hot outlet and the cold flow inlet and flow velocity below a certain limit enhanced thermal performance of a DHW tank (Arslan \& Igci, 2015). Bai et al. studied cooling process of the tank experimentally and numerically. Their results showed that tank with aspect ratio of 1:1 has the highest energy and exergy efficiency (Bai et al., 2019).

${ }^{*}$ Corresponding author. E-mail: tomas.kropas@vgtu.lt 
The exergy analysis is particularly recommended to evaluate sensible heat storage tanks' performance (Fernandez-Seara et al., 2007) as it yields efficiencies which provide a true measure of how nearly the actual process approaches the ideal (Li, 2016). Comparing the exergy and energy efficiencies of electrical heating processes of domestic hot water heaters, the exergy efficiency is very low ( 5\%) and the energy efficiency is high ( 85\%) (FernandezSeara et al., 2007). Sukchai et al. performed comparative analysis of exergy of storage tank with different solar collectors (Sukchai et al., 2017). Bielskus et al. presented analysis of two solar systems with special attention to storage tanks. An average exergy efficiency of storage tank was $3.65 \%$ in vacuum tube solar thermal system and $5.82 \%$ in flat plate solar system (Bielskus et al., 2013). Another study carried out by Deghan et al. presented results of thermal performance of a solar hot water storage tank. The energy and exergy efficiencies were found to be $47.8 \%$ and $28.7 \%$, respectively (Dehghan et al., 2005).

The analysis presented here provides a methodology describing energy and exergy efficiencies calculation for the hot water storage tank. Charging and dynamic operation modes of the storage tank are investigated experimentally and numerically. This work fills the gap in the related literature. Most of models available in literature consider a sensible heat storage tank where charging and discharging processes are evaluated separately. The article is structured as follows: Section Methodology describes in detail the used measurement equipment, assumptions of CFD modelling and main equations. The presented numerical model was used to investigate the traditional charging process and also dynamic process. Results of experimental and numerical research and their analysis are presented in Section 2. Furthermore, a computational fluid dynamics (CFD) model was validated against the experimental data and later was used to study impact of flow rate and environmental temperature on exergy efficiency of the hot water storage tank. The conclusions are summarized in Section 3.

\section{Methodology}

\subsection{The experimental set-up}

A vertical hot water storage tank was considered. Figure 1 shows a drawing of the storage tank with measuring devices Main geometrical characteristics are volume -4701 , height $-1961 \mathrm{~mm}$. The maximum working temperature is $95{ }^{\circ} \mathrm{C}$ and the maximum temperature of the internal heat exchangers is $110^{\circ} \mathrm{C}$. Maximum operating pressure is 10 bar. Tank is insulated with polyurethane foam insulation of $50 \mathrm{~mm}$. The bottom of the tank is fitted with an electric heating element used to charge the tank.

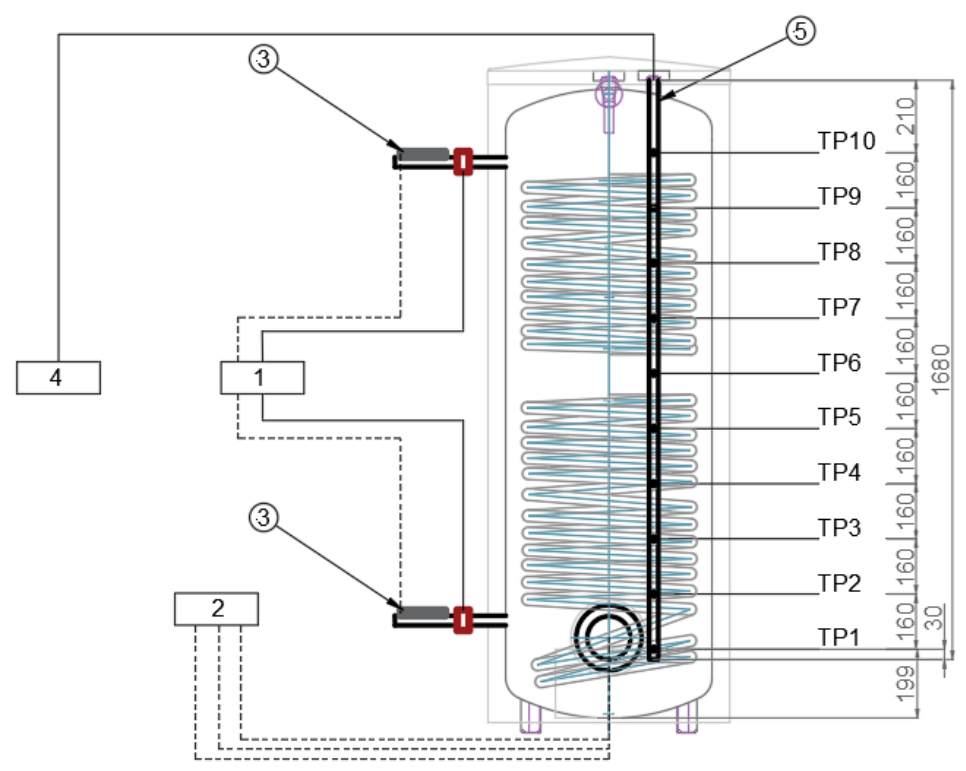

Figure 1. Schematic of the experimental set-up

The following measuring equipment was used in the experiments (equipment numbers are shown in Figure 1):

1. Flow rate meter - Ultrasonic Flow rate meter US ECHO II. Its measuring limits are $0.6 \div 15.0 \mathrm{~m}^{3} / \mathrm{h}$, operating temperature $130{ }^{\circ} \mathrm{C}$, the short-term maximum temperature $150{ }^{\circ} \mathrm{C}$, nominal pressure up to $16 / 25$ bar, accuracy class $2 \pm 0.3$ according to EN 1434 ;

2. Multifunctional Current, Voltage and Power Measuring Device MD 9272. Measurement error of current for measurements up to $40 \mathrm{~A} \pm 1.0 \%, 0.01 \mathrm{~A}$, for voltage measurement $\pm 0.5 \%, 0.01 \mathrm{~V}$;

3. Temperature sensors (thermocouple immersed) Class B, PT1000. Measurement range $-200 \div 850{ }^{\circ} \mathrm{C}$, accuracy $\pm 0.3{ }^{\circ} \mathrm{C}$ at temperature $0{ }^{\circ} \mathrm{C}$; 
4. AHLBORN Data Capture, Control, and Recorder ALMEMO 5990 2;

5. Multipoint temperature measuring device with 10 thermocouples. Thermocouple (NiCr-Ni) Type K, Class 2. Measurement range $-200 \div 1370{ }^{\circ} \mathrm{C}$, accuracy $\pm 0.05 \mathrm{~K}$. During the experiment, the temperatures were measured at ten points at different heights of the storage tank. The time-step for recording the data is 1 minute. Data is stored on ALMEMO 59902.

During the charging process, the research object is heated by an electric heating element in the lower part of the tank. The obtained results are used for numerical model validation and reliability evaluation.

During the dynamic charging-discharging process, the storage tank is charged and discharged simultaneously. The discharge of capacity takes place in volume. A separate discharge circuit is used to take the hot water from the top of the tank, cool it in the heat exchanger of the air handling unit and return it to the bottom of the storage tank after cooling. To measure the discharge mode, the temperature and the flow rate of inlet and outlet water are measured. The results of the dynamic charging-discharging process are used to validate the numerical model.

\subsection{Energy and exergy analysis}

In order to evaluate processes qualitatively, the energy efficiency of the process is calculated based on the first law of thermodynamics. The law of energy conservation states that energy conversion processes do not change the amount of energy, but merely passes from one form to another. It expresses the balance of different forms of energy in the system affected by the transformation and evaluates the energy of different forms of energy transiting between the system and the exterior, but does not assess the quality or level of that energy (Martinaitis, 2007; Dincer \& Rosen, 2013; Njoku et al., 2016).

During the charging process, this efficiency is evaluated as the ratio of the amount of power supplied by the source to the amount of capacity received by the system. The amount of energy received by the system is measured as the change in the body's internal energy using specific heat. As a result of the heat absorption process, the temperature of the material used in the storage tank rises (Alva et al., 2017). The amount of energy given to the system during the charging process is calculated as the amount of electricity consumed, assuming that all electricity has turned into heat. The energy efficiency of the charging process is calculated with the following equation:

$$
\eta_{\text {en,ch }}=\frac{Q_{\text {gained }}}{Q_{e l}}=\frac{m \cdot c_{p} \cdot \Delta T}{U \cdot I \cdot t}
$$

where: $I$ - current, A; $U$ - voltage, $\mathrm{V} ; t$ - time, $\mathrm{h} ; m$ - mass, $\mathrm{kg} ; c_{p}$ - specific heat at constant pressure, $\mathrm{kJ} /(\mathrm{kg} \cdot \mathrm{K})$; $\Delta T$ - temperature change during the process in the storage tank, $\mathrm{K}$;

In dynamic mode, the energy efficiency is calculated as the ratio of the energy actually used and the energy provided (Kropas et al., 2019):

$$
\eta_{\text {en, dyn }}=\frac{Q_{\text {useful }}}{Q_{\text {given }}}=\frac{Q_{\text {dis }}+\Delta Q_{\text {tank }}}{Q_{e l}},
$$

where: $Q_{d i s}$ - the amount of heat taken from the system, $\mathrm{kWh} ; \Delta Q_{\text {tank }}$ - change in the amount of stored energy during the process, $\mathrm{kWh} ; Q_{e l}-$ amount of electricity supplied to the storage tank, $\mathrm{kWh}$.

During the charging process, the exergy efficiency of the process is calculated as the ratio of exergy utilized (tank absorbed) to exergy delivered by the source. The calculations assume that the total amount of electricity (exergy) went to the storage tank - was transformed into heat; there is no exergy loss in the heating element:

$$
\eta_{\text {ex,ch }}=\frac{E_{\text {useful }}}{E_{\text {given }}}=\frac{Q_{s t} \cdot\left(1-\frac{T_{e}}{T_{\text {tank }}}\right)}{E_{\text {el }}},
$$

where: $T_{\text {tank }}$ - temperature in the storage tank during the process, $\mathrm{K} ; T_{e}$ - reference environment temperature, $\mathrm{K} ; Q_{s t}-$ stored energy in the storage tank during the charging processes, $\mathrm{kWh} ; E_{g i v e n}=E_{e l}$ - the amount of electricity (pure exergy) given to the storage tank, $\mathrm{kWh} ; E_{\text {useful }}$ - the amount of exergy used usefully, $\mathrm{kWh}$.

In a dynamic process, exergy efficiency is calculated as the ratio of the amount of exergy actually used, defined as the amount of exergy unloaded in the discharge loop and the change in storage tank exergy during the process and the amount of exergy delivered to the system.

$$
\eta_{\text {ex }, \text { dyn }}=\frac{E_{\text {useful }}}{E_{\text {given }}}=\frac{Q_{\text {dis }} \cdot\left(1-\frac{T_{e}}{T_{\text {tank }}}\right)+Q_{s t} \cdot\left(1-\frac{T_{e}}{T_{\text {tank }}}\right)}{E_{\text {el }}},
$$

where: $Q_{s t}$-accumulated energy in the storage tank during the charging-discharging processes, $\mathrm{kWh} ; Q_{d i s}-$ the amount of heat taken from the system, $\mathrm{kWh}$. 


\subsection{Numerical model}

The numerical model of the vertical storage tank is formed using a CFD package - ANSYS Fluent. The model solves the following equations: energy, continuity and momentum equations. The real geometric object model is created by AutoCad software and is loaded into ANSYS Fluent software (see Figure 2) where initial, boundary conditions, mathematical relationships, finite element grid and other parameters are described. The desired processes are modelled.

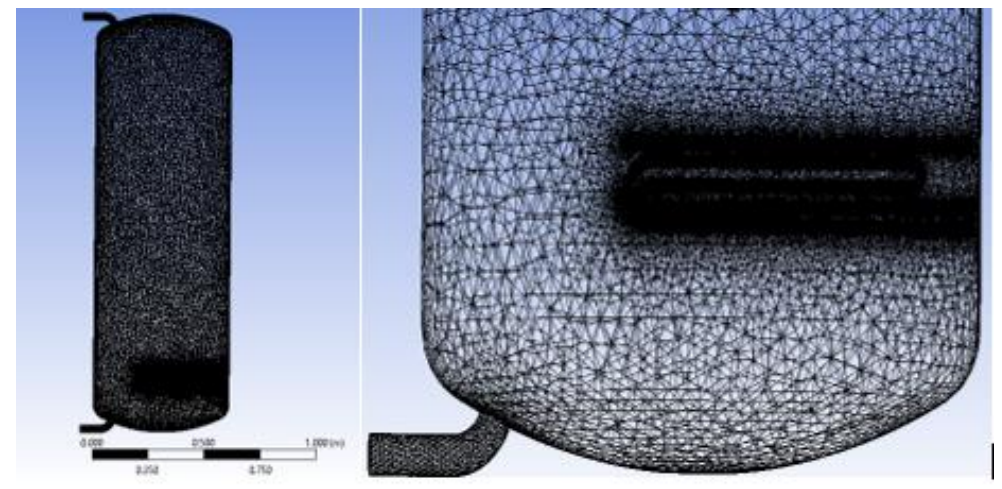

Figure 2. The model of heat storage tank in ANSYS Fluent

Heating element is placed at the bottom of the storage tank. Fluid inlet and outlet pipes for the storage tank discharge by volume are located in the upper and lower parts of the tank. At these locations the finite element grid must be compacted for more accurate results. To evaluate heat losses, an insulating material was used for the outside walls: $5 \mathrm{~cm}$ foam insulation with an overall heat transfer coefficient $\mathrm{U}=1.42 \mathrm{~W} /\left(\mathrm{m}^{2} \cdot \mathrm{K}\right)$.

Finite element sizes: minimum element size: $0.001 \mathrm{~m}$; maximum element size $0.025 \mathrm{~m}$; number of items: 2319111; mesh type: CFD Fluent.

\section{Results and discussion}

\subsection{Numerical model validation: the charging process}

Having carried out the experiment of charging process of the storage tank by an electric heating element, the duration, temperatures, voltage, current were measured and used to calculate efficiencies. The initial average storage temperature, both in CFD model and experiment is $23.5^{\circ} \mathrm{C}$. Test duration $-0.5 \mathrm{~h}$. The total amount of energy transmitted is calculated as the sum of the amount of energy supplied by each electric phase:

$$
\begin{gathered}
Q_{e l}=\left(P_{1}+P_{2}+P_{3}\right) \cdot t=\left(U_{1} \cdot I_{1}+U_{2} \cdot I_{2}+U_{3} \cdot I_{3}\right) \cdot t ; \\
Q_{e l}=(3540.14+3590.82+3513.35) \cdot 0.5=5.322 \mathrm{kWh} .
\end{gathered}
$$

During the experiment, the temperature in the storage tank rose up to $33.79{ }^{\circ} \mathrm{C}$. The process energy efficiency is calculated according to Eq. (1):

$$
\eta_{\text {en,ch,exp }}=\frac{438.95 \cdot 4.2 \cdot(33.79-23.52) \cdot \frac{1}{3600}}{5.32}=98.82 \% \text {. }
$$

During numerical simulations, the temperature in the storage tank increased up to $33.10^{\circ} \mathrm{C}$ under the same conditions. The process efficiency is:

$$
\eta_{\text {en }, \text { ch,mod }}=\frac{438.95 \cdot 4.2 \cdot(33.10-23.52) \cdot \frac{1}{3600}}{5.32}=92.17 \% \text {. }
$$

The data obtained from numerical model and experiments coincide. The resulting temperature difference is $0.69^{\circ} \mathrm{C}$. The variation of the average temperature of the heat storage tank during the charging process comparing the experimental and simulation results is presented in Figure 3.

From the graph it can be seen that the tendency of the temperature change coincides. The resulting discrepancy is $2 \%$. The resulting mismatch can be interpreted as the sum of the errors of the measuring instruments, assumptions made in the numerical model, and the influence of the actual influence of the external environment during the experiment. Therefore, it is concluded that the simulation results correspond the experimental data and the model could be used for further research. 


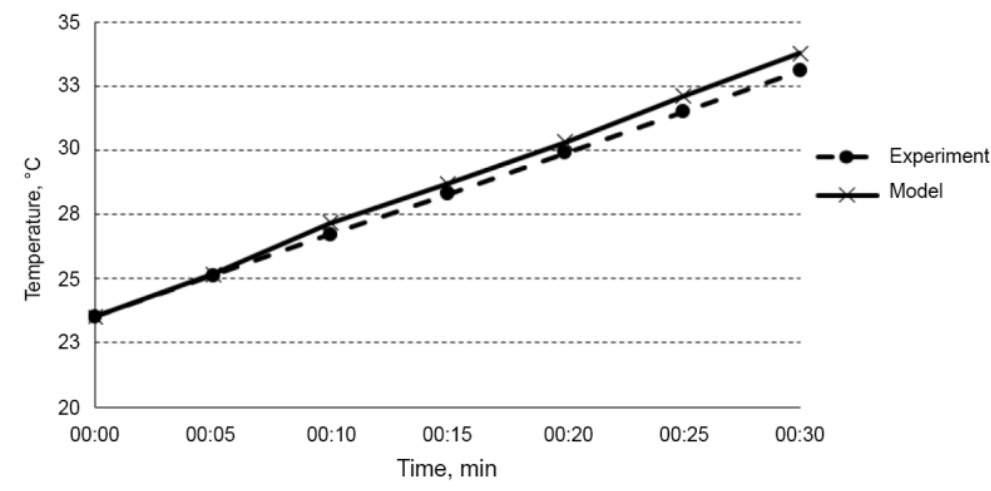

Figure 3. Comparison of average temperatures in numerical model and experiments - charging process

The thermodynamic or exergy efficiency of the process, which evaluates the quality of the process, is calculated according to Eq. (3), taking into account the environment temperature. It is assumed that the reference environment temperature during the experiment was $293.15 \mathrm{~K}$. The exergy efficiency obtained during the experiment is:

$$
\eta_{\text {ex,ch,exp }}=\frac{5.259 \cdot\left(1-\frac{293.15}{301.83}\right)}{5.32}=2.84 \% \text {. }
$$

Exergy efficiency obtained from simulation results is:

$$
\eta_{\text {ex }, \text { ch, } \bmod }=\frac{4.91 \cdot\left(1-\frac{293.15}{301.46}\right)}{5.32}=2.54 \% \text {. }
$$

The obtained results show that exergy efficiency, which evaluates the utilization of energy potential - energy quality - is vanishingly low and shows that producing heat from electricity is completely inefficient.

\subsection{Numerical model validation: the dynamic process}

During the dynamic charging/discharging process, the storage tank is heated by an electric heating element, as in the charging process, and it is simultaneously discharged through a separate circuit. The initial average water temperature in the storage tank, both in the numerical model and experiment, is $56.9^{\circ} \mathrm{C}$. Test duration is $0.5 \mathrm{~h}$. Environment temperature is $20{ }^{\circ} \mathrm{C}$.

At the beginning of the experiment, the storage tank accumulated $17.05 \mathrm{kWh}$ of heat. The amount of energy provided by the heating element, calculated according to Eq. (5), is $5.40 \mathrm{kWh}$. The amount of heat taken from the storage tank is $9.21 \mathrm{kWh}$. During this process, the average temperature of the heat storage tank dropped from $56.9^{\circ} \mathrm{C}$ to $49.31^{\circ} \mathrm{C}$. Energy efficiency calculated from experimental data is determined according to Eq. (2):

$$
\eta_{\text {en,dyn,exp }}=\frac{9.21+\frac{438.95 \cdot 4.2 \cdot(49.31-56.9)}{3600}}{5.40}=98.58 \% \text {. }
$$

Meanwhile, the exergy efficiency is obtained from Eq. (4):

$$
\eta_{\text {ex,dyn,exp }}=\frac{9.21 \cdot\left(1-\frac{293.15}{324}\right)-3.88 \cdot\left(1-\frac{293.15}{324}\right)}{5.40}=9.39 \%
$$

It is assumed that the discharging flow rate used in the numerical model is equal to the average discharging flow rate during the experiment and it is equal to $0.44 \mathrm{~kg} / \mathrm{s}$. The temperature of the return fluid from the heat transfer circuit is $30{ }^{\circ} \mathrm{C}$. The average temperature at the end of the process obtained from the numerical results is $45.09{ }^{\circ} \mathrm{C}$. Thus, the decrease of average temperature of the heat storage tank differs by $4.22{ }^{\circ} \mathrm{C}$. The comparison of the temperature variation during dynamic charging-discharging process in the model and in the experiments presented in Figure 4.

As we can see from Figure 4, the temperature trend is similar. The relative error of the average temperature of water in the storage tank comparing numerical results and experimental data is calculated. The resulting discrepancy is $2.75 \%$ and the overall energy balance is achieved. This allows the model to be used for further research - to investigate how the dynamic operation mode of the vertical storage tank depends on discharge flow rate. 


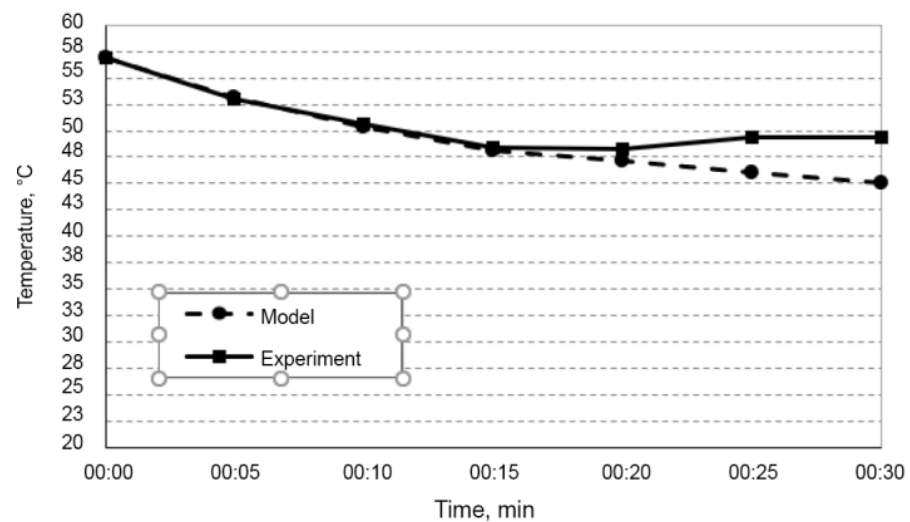

Figure 4. Comparison of temperatures obtained from numerical model and experiments - dynamic charging-discharging process

\subsection{Influence of discharging water flow rate on energy and exergy efficiency}

Energy and exergy efficiencies are calculated and analysed for different discharge loop flow rates: $0.11 \mathrm{~kg} / \mathrm{s}$ and $0.44 \mathrm{~kg} / \mathrm{s}$. The initial conditions in ANSYS Fluent model keep the same as before. The temperature distribution using different discharge flow rates after $5 \mathrm{~min}, 15 \mathrm{~min}$ and $30 \mathrm{~min}$ are presented in Figure 5.

a)

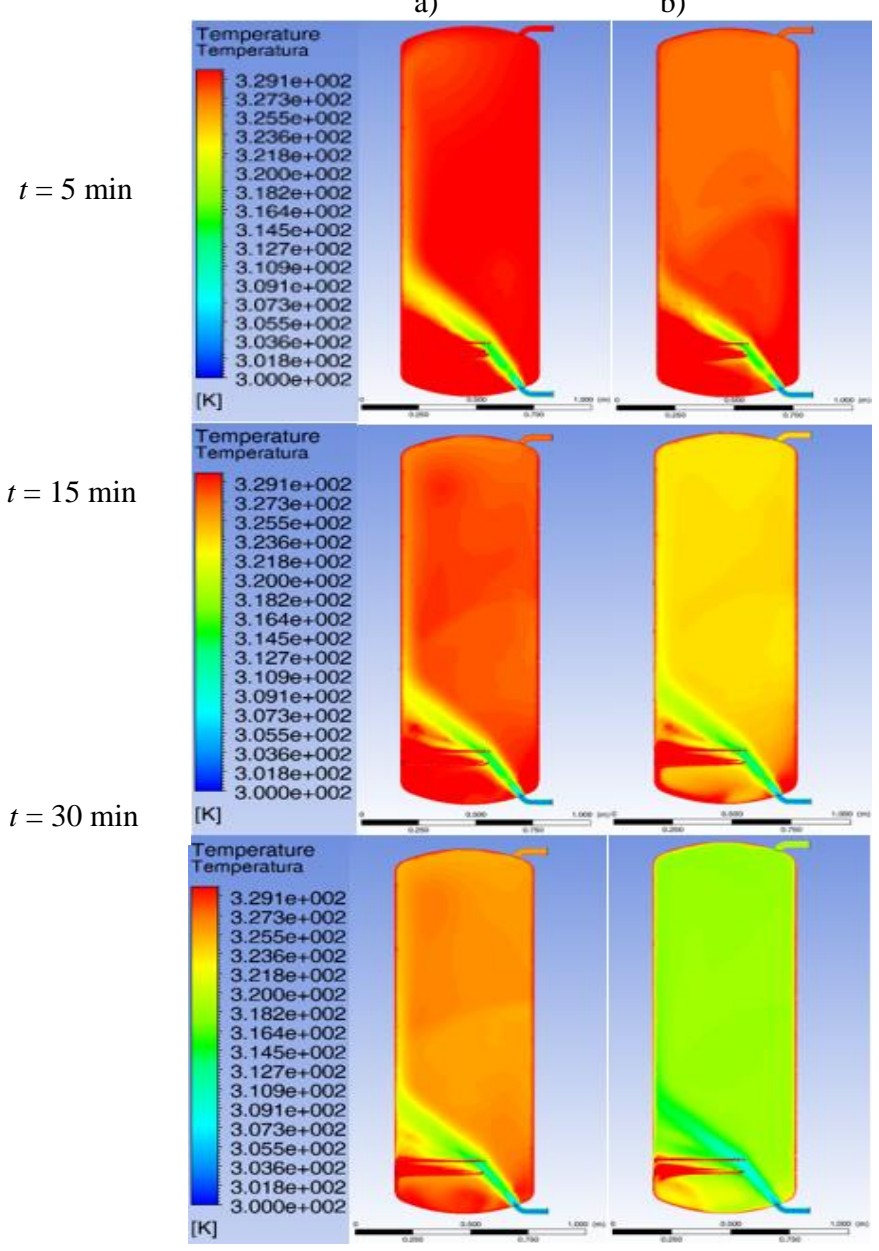

Figure 5. Dynamic process of charge-discharge cycle of the storage tank.

Discharge flow rates: $\mathrm{q}=0.11 \mathrm{~kg} / \mathrm{s}(\mathrm{a}), \mathrm{q}=0.44 \mathrm{~kg} / \mathrm{s}(\mathrm{b})$

Figure 5 presents how the numerical results differ depending on the discharge flow rate and the process time. The results show that at the beginning of the process the temperature distribution in the tank is similar, but over time the 
storage tank with a higher discharge flow rate cools down faster (see Figure 5b). Further the impact of the flow rate on energy and exergy efficiency is examined.

The return temperature of water in the discharge circuit in the numerical model is $30{ }^{\circ} \mathrm{C}$. The amount of heat taken from the storage tank is $5.70 \mathrm{kWh}$. During this process, the average temperature of the storage tank dropped from $56.9{ }^{\circ} \mathrm{C}$ to $55.92{ }^{\circ} \mathrm{C}$, which represents a change in the internal energy of $0.50 \mathrm{kWh}$. The thermal (energy) efficiency calculated from Equation (2) is $96.27 \%$. The exergy efficiency determined from Eq. (4) is $10.70 \%$.

Exergy efficiency is significantly lower than energy efficiency when heat is generated from electricity. However, when the part of the energy is used purposefully, the exergy efficiency is higher than just producing heat from the pure exergy - electricity.

\subsection{Influence of environment temperature on exergy efficiency}

In order to analyse influence of environment temperature on exergy efficiency, two different climatic zones were selected for the analysis. The first one is the Dfb (warm summer subtype) climate. It is predominant in eastern Europe and southern Scandinavia. Areas with this continental climate subtype have average warmest monthly temperatures below $22{ }^{\circ} \mathrm{C}$. Winters are pompous and cold. The second climatic zone is the Csa (hot summer Mediterranean climate) climate. Mediterranean or dry summer climates are characterized by dry summers and mild, wet winters.

The cities selected for each of these climate zones are the capitals of the typical countries of these climate zones. Vilnius is selected for Dfb climate zone and Rome - for Csa. Environmental temperatures and their durations are taken from weather data file in TRNSYS software. The most frequent temperature during the year is chosen as the reference environment temperature for the calculation of exergy efficiency.

Examination of hourly temperature data in Vilnius shows that most of the year the environment temperature is $\sim 0{ }^{\circ} \mathrm{C}$ which lasts 339 hours. Assuming such environment temperature, the exergy efficiency of the dynamic process according to Eq. (4) is $16.54 \%$.

Examining the hourly temperature data for Rome, the environment temperature for most of the year is $13{ }^{\circ} \mathrm{C}$. It lasts 442 hours. Assuming such environment temperature, the exergy efficiency of the dynamic process is $12.75 \%$.

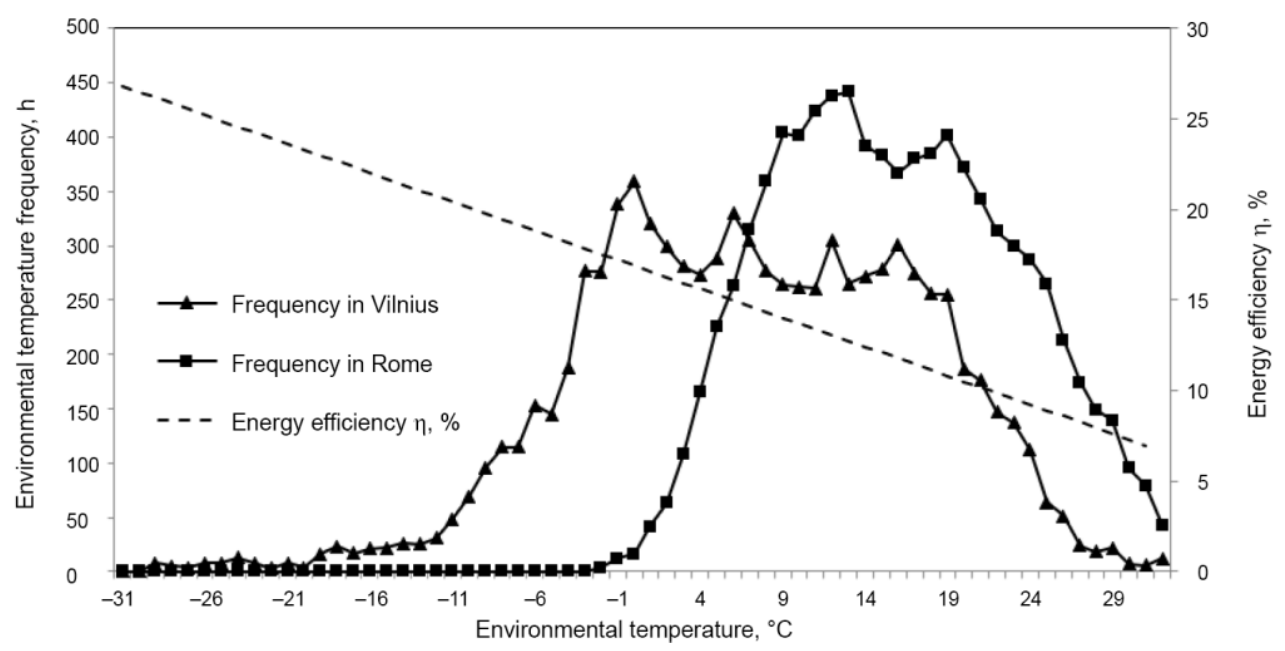

Figure 6. Environment temperature frequency in different climate zones and exergy efficiency

Figure 6 shows the distribution of the environment temperature over the year in different cities with different climates. It can be seen that Rome is predominantly warmer than Vilnius, but this obviously has a negative impact on the exergy efficiency of the system under the same operating conditions. The results show that the exergy efficiency of the storage tank for the dynamic process in different climatic zones will be different, although the system parameters themselves do not change. This reveals that at lower environment temperatures $\left(T_{e}\right)$ the exergy efficiency will be higher than at higher environment temperatures because in this case the energy potential is higher.

\section{Conclusions}

In order to design efficient heat storage system, it is necessary to experimentally and numerically study their operation and qualitatively and quantitatively evaluate its performance. In this article the charging and dynamic charging-discharging modes of the heat storage tank were analysed experimentally and numerically. It was found that the energy efficiency (by the first law of thermodynamics) of the processes in all cases differs from the exergy one. The energy efficiency was in all cases higher than the exergy one, which takes into account energy quality rather than quantity and includes both laws of thermodynamics and impact of environment. However, exergy efficiency is different in different 
climatic zones and is mainly influenced by the prevailing environment air temperature. The results showed that the conversion of electricity into heat is exergically inefficient.

The numerical model using computational fluid dynamics - CFD was validated on the basis of experimental results. It allowed to compare the dynamic operation efficiency of the system and influence of the discharge flow rate. The energy and exergy efficiencies obtained under different storage tank discharge flow rates were insignificant. With a discharge flow rate of $0.44 \mathrm{~kg} / \mathrm{s}$, the energy efficiency is $98.58 \%$ and the exergy efficiency is $9.39 \%$. Reducing the discharge flow rate to $0.11 \mathrm{~kg} / \mathrm{s}$ resulted in an energy efficiency of $96.27 \%$ and an exergy efficiency of $10.70 \%$. This indicated that the discharge rate had little effect on the energy and exergy efficiency.

Analysing the influence of reference environment temperature on the exergy efficiency of the dynamic operation mode of the heat storage tank in different climatic zones (two cities: Vilnius and Rome): Dfb and Csa, the corresponding results were obtained. When the most frequent temperature during the year was selected the exergy efficiency of the same processes was $16.54 \%$ in the case of Vilnius and $12.75 \%$ in the case of the city of Rome. This indicates that higher environment temperature gives lower exergy efficiency of the system. This dependence is due to the fact that the smaller difference between the environment temperature and the average temperature of the storage tank translates into a reduction in energy potential.

\section{References}

Alva, G., Liu, L., Huang, X., \& Fang, G. (2017). Thermal energy storage materials and systems for solar energy applications. Renewable and Sustainable Energy Reviews, 68(Part 1), 693-706. https://doi.org/10.1016/j.rser.2016.10.021

Arslan, M., \& Igci, A. A. (2015). Thermal performance of a vertical solar hot water storage tank with a mantle heat exchanger depending on the discharging operation parameters. Solar Energy, 116, 184-204. https://doi.org/10.1016/j.solener.2015.03.045

Bai, Y., Yang, M., Wang, Z., Li, X., \& Chen, L. (2019). Thermal stratification in a cylindrical tank due to heat losses while in standby mode. Solar Energy, 185, 222-234. https://doi.org/10.1016/j.solener.2018.12.063

Bielskus, J., Januševičius, K., \& Martinaitis, V. (2013). Vakuuminių ir plokščiųjų saulès kolektorių sistemų ekserginių efektyvumų palyginimas. Mokslas - Lietuvos ateitis / Science - Future of Lithuania, 5(4), 404-409. https://doi.org/10.3846/mla.2013.64

Chandra, P. Y., \& Matuska, T. (2019). Stratification analysis of domestic hot water storage tanks: A comprehensive review. Energy \& Buildings, 187, 110-131. https://doi.org/10.1016/j.enbuild.2019.01.052

Dehghan, A. A., Hosni, M. H., \& Shiryazdi, S. H. (2005). Experimental evaluation of the thermal behaviour of a vertical solar tank. In IMECE2005 2005 ASME International Mechanical Engineering Congress and Exposition, ition November 5-11, 2005, Orlando, Florida, USA, (pp. 1-6).

Dincer, I., \& Rosen, M. A. (2013). Exergy analysis of thermal energy storage systems. Exergy (2 ${ }^{\text {nd }}$ ed.). Energy, Environment and Sustainable Development (Chapter 9, pp. 133-166). https://doi.org/10.1016/B978-0-08-097089-9.00009-77

Džiugaitè-Tumènienè, R., \& Streckienè, G. (2014). Solar hot water heating system analysis using different software in single family house. In The $9^{\text {th }}$ International Conference "Environmental Engineering”, 22-23 May 2014, Vilnius, Lithuania. Vilnius, p. 9. https://doi.org/10.3846/enviro.2014.258

Fernandez-Seara, J., Uhía, F. J., \& Sieres, J. (2007). Experimental analysis of a domestic electric hot water storage tank. Part I : Static mode of operation. Applied Thermal Engineering, 27(1), 129-136. https://doi.org/10.1016/j.applthermaleng.2006.05.006

Fertahi, S., Jamil, A., \& Benbassou, A. (2018). Review on Solar Thermal Stratified Storage Tanks (STSST): Insight on stratification studies and efficiency indicators. Solar Energy, 176, 126-145. https://doi.org/10.1016/j.solener.2018.10.028

Ghaddar, N. K. (1994). Stratified storage tank influence on performance of solar water heating system tested in Beirut. Renewable Energy, 4(8), 911-925. https://doi.org/10.1016/0960-1481(94)90225-9

Haller, M. Y. et al. (2009). Methods to determine stratification efficiency of thermal energy storage processes - Review and theoretical comparison. Solar Energy, 83(10), 1847-1860. https://doi.org/10.1016/j.solener.2009.06.019

Kropas, T., Streckienė, G., \& Frik, A. (2019). Akumuliacinės talpyklos dinaminio veikimo eksperimentinis ir skaitinis tyrimas. Mokslas - Lietuvos ateitis / Science - Future of Lithuania, 11, 1-5. https://doi.org/10.3846/mla.2019.10576

Li, G. (2016). Sensible heat thermal storage energy and exergy performance evaluations. Renewable and Sustainable Energy Reviews, 53, 897-923. https://doi.org/10.1016/j.rser.2015.09.006

Martinaitis, V. (2007). Termodinamine analizè. Technika. https://doi.org/10.3846/875-S

Njoku, H. O., Ekechukwu, O. V., \& Onyegegbu, S. O. (2016). Comparison of energy, exergy and entropy generation-based criteria for evaluating stratified thermal store performances. Energy and Buildings, 124, 141-152. https://doi.org/10.1016/j.enbuild.2016.04.062

Rahman, A., Smith, A. D., \& Fumo, N. (2016). Performance modeling and parametric study of a stratified water thermal storage tank. Applied Thermal Engineering, 100, 668-679. https://doi.org/10.1016/j.applthermaleng.2016.01.163

Streckiene, G., \& Miseviciute, V. (2011). Research of operation modes of heat storage tank in CHP plant using numerical simulation. Scientific Journal of Riga Technical University, 6, 91-99. https://doi.org/10.2478/v10145-011-0013-3

Sukchai, S., Mensin, Y., \& Wansungnern, W. (2017). Comparative analysis of exergy and efficiency for stratified thermal storage tank with solar flat plate and evacuated tube collectors. Applied Mechanics and Materials, 855, 114-118. https://doi.org/10.4028/www.scientific.net/AMM.855.114

Wang, Z., Zhang, H., Huang, H., Dou, B., Huang, X., \& Goula, M. A. (2019). The experimental investigation of the thermal stratification in a solar hot water tank. Renewable Energy. 134, 862-874. https://doi.org/10.1016/j.renene.2018.11.088 